Yevheniia Ziabina,

Sumy State University, Ukraine

(iD) ORCID ID, 0000-0003-0832-7932

email: e.ziabina@buh.sumdu.edu.ua

Aleksy Kwilinski,

Dr.Sc., The London Academy of Science and Business, United Kingdom

iD ORCID ID, 0000-0001-6318-4001

email: a.kwilinski@london-asb.co.uk

Tatiana Belik,

Sumy State University, Ukraine

Correspondence author: e.ziabina@buh.sumdu.edu.ua

\title{
HR MANAGEMENT IN PRIVATE MEDICAL INSTITUTIONS
}

Abstract. The article summarizes the arguments and counter-arguments within the scientific discussion on improving the HR management system in medical centers through HR policy tools. The study's main purpose is to form proposals and focus on the prospects for the development of HR management in medical institutions. Systematization of learned treatises and approaches on the development of HR management systems showed problems in HR management's current methods and systems. The urgency of solving this scientific problem is that the improvement of HR policy could effectively form and modernize medical organizations' personnel management systems. The study of improving the HR management system in medical centers was carried out in the following logical sequence: considering the basics of personnel management in the private organizations; studying the methods and current trends in personnel management; analyzing the current system of HR management and personnel management on the example of medical institutions of Ukraine; developing recommendations for improving the HR policy of medical centers have been formed considering the obtained results. The methodological tools of the study were the methods of comparison, the BSC system of Kaplan and Norton, the fundamental provisions of personnel management, the calculation method and the method of data analysis, and the Gantt chart. The object of the study is the HR policy of medical institutions in Ukraine. The article presents the empirical analysis results based on the identified problems of organizing a personnel management system. The essence and features of the HR policy of medical centers were determined. In the study, the authors considered the state of medical centers' staffing and HR management methods in health care. To investigate the organizational structure and personnel in the current situation of HR management of medical centers, the analysis of personnel and financial indicators was conducted. The findings showed the deficiencies in the personnel document management and HR management system of medical centers and the reasons for staff turnover. The comparison method, Kaplan and Norton's BSC system, Gantt chart, calculation, and data analysis allowed identifying the ways to improve the existing HR management system in organizations.

Keywords: personnel management, HR management, HR policy, intangible methods of motivation, staff training.

Introduction. In current conditions, people are the most valuable assets for any organization since they are individually and collectively contribute to achieving common goals. Effective human resources management ensures the market stability of the organization, the success of its operation in a competitive environment, and the prospects for strategic development. In modern business, HR management becomes especially relevant, organized to minimize staff costs and ensure the organization's high performance. Nowadays, it is almost undoubted that the direct dependence of organization socioeconomic results on the quality and efficiency of the human resources management system. Therefore, the study of issues related to the creation and development of personnel management systems is only becoming more relevant in recent years.

Cite as: Ziabina, Ye., Kwilinski, A. \& Belik, T. (2021). HR Management in Private Medical Institutions. Health Economics and Management Review, 1, 30-36. http://doi.org/10.21272/hem.2021.1-03

30 
Literature Review. Foreign and Ukrainian academic communities have studied the problems and prospects of HR management and personnel management. The publications and scientific works in HR management by foreign specialists considered the change of HR management concepts and the evolution of the personnel management concept. It stands to mention the most productive scientist such as Roehling et al. (2005), Losey (1999), Cascio (2012), Gavin and Dileepan (2002), Ceylan (2013) and others. Notably, the scientists mentioned above determined the content of a modern adapted personnel management system and its differences from HR management.

On the other hand, the Ukrainian authors quite often considered HR management in terms of standard personnel work and organizations' personnel services techniques. Among the authors who investigated the HR management adaptation under the Ukrainian realities, it is worth highlighting Gridin (2017), Bala (2018), Zagreva (2015), Timokhina (2013), Boychenko (2019), llyash and Blokhin (2018), Tarasova (2018), Tereshchenko and Zelenskaya (2018), Shvets (2013), Zastrozhnikova (2018), Dyadyk (2019).

Methodology and research methods. This study involved the HR policy tools. Based on the identified problems in the organization's personnel management system, the essence and features of the HR policy of the medical center were determined. The medical center staffing state and staffing methods in health care were considered. Besides, the current state of personnel management was studied in the case of an actual medical center. The challenging moments in the current methods and systems of HR management were identified. The personnel analysis findings and financial indicators allowed investigating the medical center's organizational structure and personnel under current HR management affairs. The study presents the deficiencies in the personnel document management and HR management system of the medical center. The authors identified the staff turnover. For improving the existing HR management system, the comparison method, Kaplan and Norton's BSC system, Gantt chart, calculation method, and data analysis method were involved.

Results. The specifics of the organization's HR and personnel management primarily depend on the strategic activities for the use of human resources. Moreover, they are implemented in the areas as follows:

- selection, planning, creation of a progressive team, training, staff motivation, etc.;

- work with personnel, which covers all personnel services and personnel management issues.

Notably, this area includes operational management. The areas of HR management mentioned above assume that the manager has a sufficient level of competence such as professional, methodological (systematical thinking ability), social (teamwork ability), and temporary (ability to use time rationally) features. In turn, the main methods of HR management are as follows:

- economic methods: methods and means of influencing employees by comparing costs and performance (material incentives and disincentives, salary, cost, profit, selling price);

- organizational and managerial methods: direct influence on staff, which are directive and mandatory;

- socio-psychological methods: motivation, moral encouragement, socio-psychological planning, etc.

It is worth mentioning that the economic methods of HR management ensure the progressive development of the entire organization.

The functions of HR management are classified into general and specific groups. In turn, all team members and managers, regardless of their position, perform the general HR management functions. These functions cover logistics, planning, control, and motivation. On the other hand, specific HR management functions are determined by the functional division of labor among structural units and performers. Notably, the main goals of these functions are competitiveness growth, ensuring the social efficiency of the team, increasing performance, and maximizing profit. 


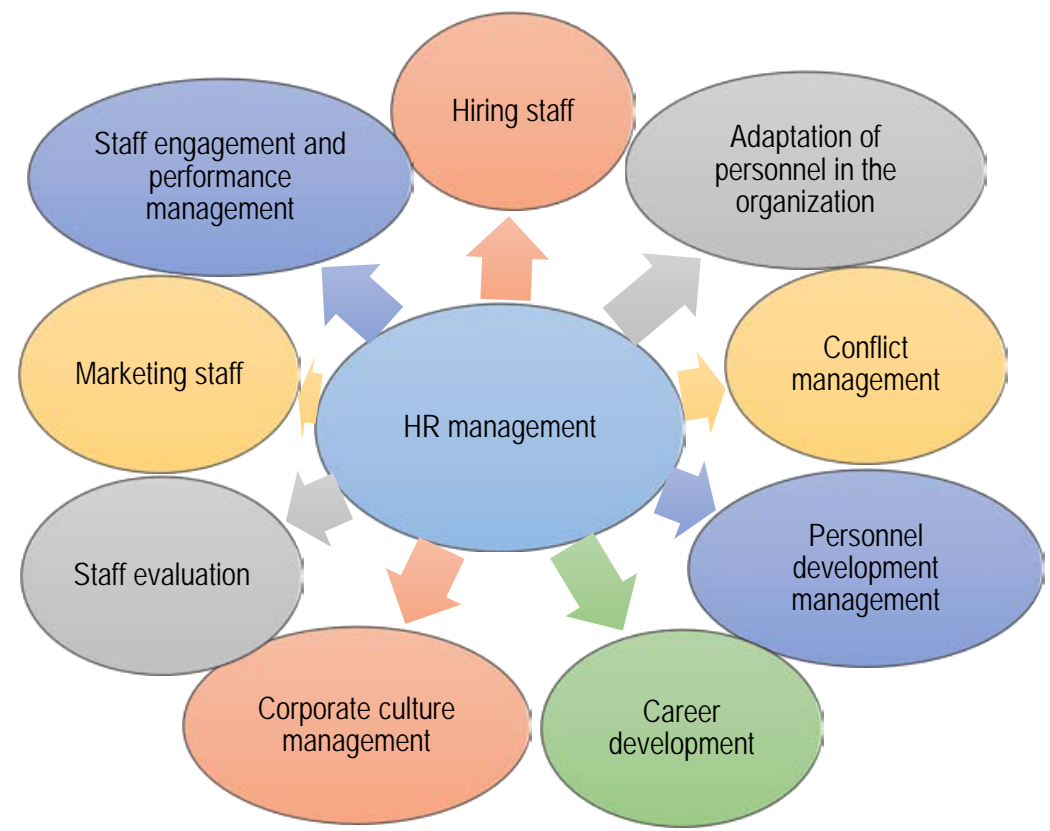

Figure 1. Structure and composition of HR management

Sources: develiped by the authors based on (Rudenko et al., 2013).

Figure 1 shows that HR management methods are based on socio-psychological laws. Thus, psychology studies human behavior, changes in his actions, and ways to identify conditions that affect the individual. Sociology expands the scope of the concept of the individual, uniting several people into a single team. In turn, socio-psychological methods of HR management are ways of influence based on socio-psychological factors.

Features of some aspects of the HR department activity or HR specialist performance describe the peculiarities of the private medical institutions' HR management system organization. The consideration of the medical personnel recruitment process showed that applicants rule the labor market. Thus, private medical institutions compete for worthy candidates, offering various bonuses. Notably, negotiations can take more than one month. The recruitment process requires analyzing different options, judging, weighing, consulting with colleagues in the medical field (Zaika, 2017). It stands to mention that this situation is slightly different in the case of recruiting junior medical staff in private clinics. Thus, the budget institutions compete with commercial ones and often in favor of the public sector. Nurses perceive commercial clinics as an additional source of income. However, regularly they prefer public health facilities because they seem more reliable. Besides, recent changes and reforms in the health care system have led to increased salaries in public institutions. Nowadays, commercial centers are forced to look for compromises: recruiting part-time employees, inviting consultative receptions with hourly payment, and creating other advantages. It stands to mention that the private clinics are attractive for university graduates. Thus, private clinics «hunt» for the guru in the medical industry. They expect that patients will prefer the famous doctor. Therefore, the clinic's profit will grow. However, despite the acute shortage of staff, young professionals are also in demand. They have every chance to take a starting position in private medicine. 
Regarding the criteria selection for work in private medical clinics, the medical knowledge and experience are insufficient to work in the private clinic. It is essential to be customer-orientated, offer a good service, explain the treatment plan, justify the chosen treatment tactics, etc. Moreover, the ability to enlist support in the clinic is important too.

It stands to note that many doctors aren't patient orientation. Therefore, there is crucial to provide doctors with regular training and feedback control. The current patients are contentious and check the medical prescription using the Internet, articles, etc. With this, the doctor must clearly and masterly argue and defend the point of view to eliminate the patient's anxiety. Thus, the doctor requires endurance and calm. Considering the trends in searching and selecting personnel by the HR management department of private medical institutions, any doctor is in demand. However, a significant advantage is the versatility of the specialist. Figure 2 demonstrates the main tools for finding HR management staff of private medical institutions.

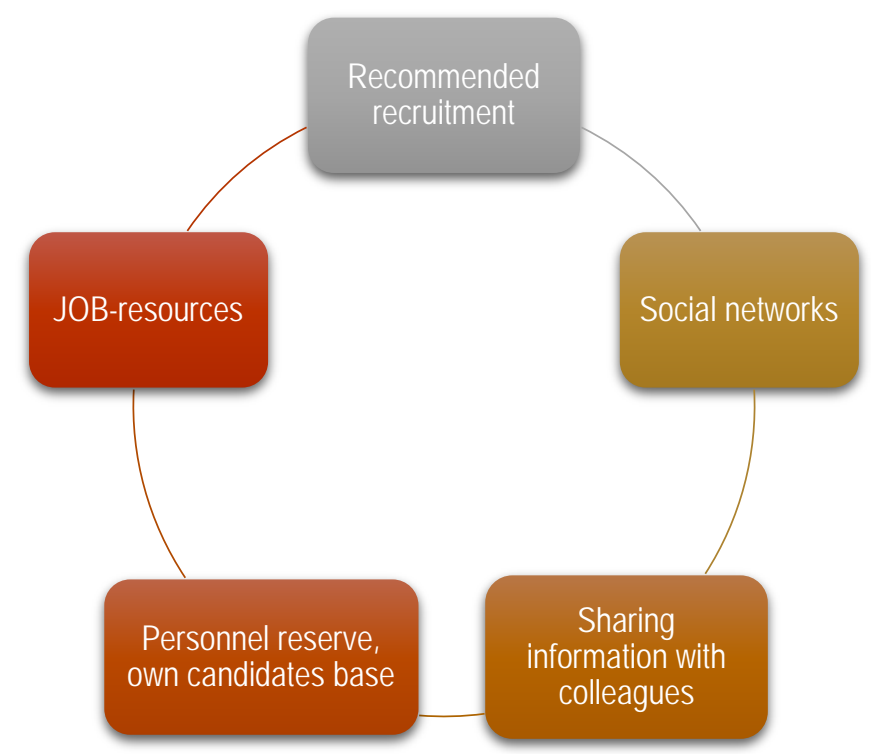

Figure 2. Basic staff search tools for private medical institutions

Sources: develiped by the authors based on (Bogdan et al., 2019).

Notably, health care is the specific labor market. Therefore, the main search tool is a recommended recruitment or «word of mouth». Looking for a job, doctors, firstly, ask their friends and colleagues. Their recommendations and advice significantly influence their decisions to go or not to go for an interview to a private clinic.

On the other hand, the important criterion is the employer brand. Thus, if the clinic's management behaved incorrectly with one doctor, then the lousy reputation could go far beyond the clinic. It is necessary to dismiss employees competently and on a positive note. Therefore, it will provide the chance to get the recommendation even from a fired specialist (Shkilnyak et al., 2018). It is worth highlighting the existence of the «headhunting» method in medicine. HR managers try to lure professional and highly experienced doctors from other clinics. Herewith, the personnel management service of private clinics «hunts» for medical specialists from budgetary institutions, offering them much better working conditions and material 
remuneration. Besides, an important indicator to trust the employer is doctors' recommendations to invite the necessary specialists to the clinic for vacancies (Shkilnyak et al., 2018).

Table 1. Education levels and the age structure of medical center employees

\begin{tabular}{c|c|c|c|c|c}
\multirow{2}{*}{$\begin{array}{c}\text { Level of education of } \\
\text { employees }\end{array}$} & $\%$ & Age, years & $\%$ & Age, years & $\%$ \\
\hline Higher Education & 68 & $\mathbf{2 0 - 3 0}$ & 13,6 & $\mathbf{5 1 - 6 0}$ & 22,7 \\
\hline $\begin{array}{c}\text { Vocational secondary } \\
\text { education }\end{array}$ & 23 & $31-40$ & 36,4 & $61-70$ & 4,6 \\
\hline Secondary education & 9 & $41-50$ & 22,7 & $70+$ & 0
\end{tabular}

Note:\% is a percentage of the total

Sources: develiped by the authors.

Table 1 shows that administrative and managerial staff and doctors have higher education; nurses vocational secondary education; the service personnel - secondary education. The mentioned above is very natural because the type of performed work puts forward its requirements for the quality of education of employees. On the other hand, most employees are in the most productive age from 30 to 50 years, combining high qualifications with professional experience.

Conclusions. Nationwide health care reform is underway. Thus, it complicates the process of health care personnel management in private and public health facilities. The findings showed that all management aspects transform (organizational structures, forms and management styles). Meanwhile, the burden on public and private medical institutions remains consistently high, while it even increases. The healthcare system's personnel policy could be described as a multifaceted, complex, and multilevel socio-cultural phenomenon. It is determined by the mechanism of social relations in the institution between the administration and employees. The HR policy helps the organization to adapt to the external environment and integrate the internal environment. The penetration level of the personnel control process can be considered as culture HR policy. In turn, the HR policy implementation could be in writing form if all employees must read any special documents, or orally if there is HR policy is a list of conceptual laws and regulations. It should be noted that the management of the medical institution should understand and support HR policy. Therefore, the best solution is to develop special documents. HR policy of a medical institution covers a full range of areas related to personnel management such as staffing, evaluation, career management, remuneration and bonuses, training and education, motivation, and incentives, etc. To retain employees, especially the highly-skilled, HR policy must combine qualities such as flexibility, dynamism, and stability on the other. follows:

The obtained results on analyzing HR policy of medical centers in Ukraine allowed concluding as

1. The staff of medical clinics is highly qualified.

2. Employees value their jobs. Staff turnover is constantly low.

3. HR policy in clinics is not documented, but all the necessary work areas are implemented.

4. There are no employees who are assigned the duties of HR-manager.

5. Employees understand the necessity of HR policy development to increase efficiency.

In turn, under findings, the study provides the following recommendations as follows:

1. Develop and implement «Regulations on the approval of HR policy and personnel management system in medical centers».

2. Designate an individual responsible for HR policy (administrator of the center).

3. Develop the measures for intangible motivation (corporate events).

4. Improve the depreciation system. 
Therefore, improving the competence of personnel management will improve the socio-psychological climate in the team, the level of discipline, and the individual contribution of employees to the overall results of the medical center. Besides, the project implementation will lead to economic performance growth.

Author Contributions: conceptualization, Ye. Z. and T. B.; methodology, Ye. Z.; validation, Ye. Z. and T.B.; formal analysis, T. B.; investigation, Ye.Z.; resources, T. B.; data curation, Ye. Z.; writingoriginal draft preparation, Ye. Z.; visualization, T. B.; supervision, Ye. Z.; project administration, Ye. Z. and T. B.

Funding: This research received no external funding.

\section{References}

Bala, R. D. (2018). The role of the personnel management body in solving the problems of staff turnover in enterprises in the context of the growing international labor migration of young people. Young Scientist, 2, 678-681. [Google Scholar]

Bogdan, D., Boyko, A., Vasilkova, A., Vezhnovets, T., Zvinchuk, O., Latipov, A., .. \& Sereda, Yu. (2019). Human resources of the health care system in Ukraine Situation analysis. [Google Scholar]

Bordzan, S. (2016). Improving socio-psychological methods of enterprise management. Eastern Europe: Economics, Business and Management, 1 (06), 24-31. [Google Scholar]

Boychenko, O. (2019). Key HR-trends of Ukraine 2019. Report Global Human Capital Trends. Analysis and prospects (master's thesis, Sumy State University). [Google Scholar]

Cascio, W. F. (2012). Methodological issues in international HR management research. The International Journal of Human Resource Management, 23(12), 2532-2545. [Google Scholar] [CrossRef]

Ceylan, C. (2013). Commitment-based HR practices, different types of innovation activities and firm innovation performance. The International Journal of Human Resource Management, 24(1), 208-226. [Google Scholar] [Google Scholar]

Dyadyk, T. (2019). The need for HR-marketing in today's labor market. Market Infrastructure, 33, 246-253. [Google Scholar]

Gavin, T. A., \& Dileepan, P. (2002). Stress!!: Analyzing the culprits and prescribing a cure. Strategic Finance, 84(5), 50. [Google $\underline{\text { Scholar] }}$

Gridin, O. (2017). HR management in modern organizations: features and prospects of implementation. Bulletin of the Petro Vasylenko Kharkiv National Technical University of Agriculture, (185), 160-172. [Google Scholar]

Ilyash, O., \& Blokhin, P. (2018). The future of HR management: trends, risks, motivation. [Google Scholar]

Losey, M. R. (1999). Mastering the competencies of HR management. Human Resource Management: Published in Cooperation with the School of Business Administration, The University of Michigan and in alliance with the Society of Human Resources Management, 38(2), 99-102. [Google Scholar] [CrossRef]

Roehling, M. V., Boswell, W. R., Caligiuri, P., Feldman, D., Graham, M. E., Guthrie, J. P., ... \& Tansky, J. W. (2005). The future of HR management: Research needs and directions. Human Resource Management: Published in Cooperation with the School of Business Administration, The University of Michigan and in Alliance with the Society of Human Resources Management, 44(2), 207216. [Google Scholar] [CrossRef]

Rudenko, O., Usachenko, L., \& Shturkhetsky, S. (2013). HR management system and strategy for public administration: textbook. way. Rudenko OM, Usachenko LM, Shturkhetsky SV-K: LLC «SPE «Interservice».

Shkilnyak, M., Zhelyuk, T., Vasina, A., Dudkina, O., Popovych, T., \& Ovsyanyuk-Berdadina, O. (2018). Modernization of health care system management in the context of medical reform. Bulletin of Ternopil National University of Economics, 4, 168-180. [Google Scholar]

Shvets, I. (2013). HR management: problems, strategies and prospects: a collective monograph. Donetsk: «DonNTU».

Tarasova, K. (2018). Features of HR management for the digital world: trends and prospects. Young scientist, 3(2), 708-711. [Google Scholar]

Tereshchenko, K., \& Zelenskaya, D. (2018). HR management and the labor market: aspects of interaction. Economic Bulletin of the Zaporozhye State Engineering Academy, (6), 173-178. [Google Scholar]

Timokhina, O. (2013). Personnel management as a key element in the enterprise management system. Economy and region, 4, 106-112. [Google Scholar]

Vasilik, A. (2014). Modern challenges and innovative practices of personnel management. Socio-labor relations: theory and practice, 1, 306-314. [Google Scholar]

Volyanyuk, N., Lozhkin, G., Vinoslavskaya, O., Blokhina, I., Kononets, M., Moskalenko, O., ... \& Andriytsev, B. (2019). Social Psychology. [Google Scholar]

Zagreva, V. (2015). Personnel management in the management system of organizations. Scientific Bulletin of the Lesia Ukrainka East European National University. Pedagogical sciences, 1, 86-90. [Google Scholar]

Zaika, V. (2017). Medical management. The practice of managing a medical institution, 1, 52-57. 
Zastrozhnikova, I. (2018). Formation of personnel reserve as one of the functions of HR management of the civil service. [Google Scholar]

євгенія Зябіна, Сумський державний університет (Україна);

Олексій Квілінський, Dr.Sc, Лондонська академія науки і бізнесу (Великобританія);

Тетяна Белік, Сумський державний університет (Україна)

HR-менеджмент у приватних медичних закладах

Стаття узагальнює аргументи та контраргументи в межах наукової дискусії щодо удосконалення системи HRменеджменту в медичних центрах за допомогою інструментів HR-політики. Основною метою проведеного дослідження $\epsilon$ формування пропозицій та фокусування на перспективах розвитку HR-менеджменту в медичних закладах. Систематизація літературних джерел та підходів до розв'язання проблеми розвитку системи HR-менеджменту засвідчила існування низки проблем у чинних методах та системах HR-менеджменту. Актуальність розв'язання наукової проблеми полягає в тому, що вдосконалення HR-політики може бути ефрективним при формуванні та модернізаціі системи управління персоналом медичних організацій. Дослідження питань вдосконалення системи HR-менеджменту в медичних центрах здійснено в наступній логічній послідовності: розглянуто основи організації управління персоналом приватних організацій; досліджено методи та актуальні тренди в управлінні персоналом; проведено аналіз чинної системи HR-менеджменту та управління персоналом на прикладі медичних закладів України; враховуючи отримані результати, сфоормовано рекомендації щодо вдосконалення HR-політики медичних иентрів. Методичним інструментарієм проведеного дослідження стали методи порівняння, система BSC Каплана і Нортона, фундаментальні положення управління персоналом, розрахунковий метод та метод аналізу даних, діаграма Ганта. Об'єктом дослідження обрано HR-політику медичних закладів в Україні. В статті представлено результати емпіричного аналізу базуючись на виявлених проблемах організації системи управління персоналом. Авторами визначено сутність та особливості роботи HR-політики медичних центрів. Розглянуто стан кадрового забезпечення медичних центрів, а також методи кадрової роботи у сфері охорони здоров'я. За допомогою аналізу кадрових та фінансових показників, структури та персоналу в організаиії було досліджено поточну ситуацію в $H R$-менеджменті медичних иентрів. За результатами виявлено недоліки у кадровому документообігу та системі HR-менеджменту медичних иентрів та визначено причини плинності кадрів. За допомогою методу порівняння, системи BSC Каплана і Нортона, діаграми Ганта, розрахункового методу та методу аналізу даних визначено шляхи вдосконалення чинної системи HR-менеджменту в організаціях.

Ключові слова: управління персоналом, HR-менеджмент, HR-політика, нематеріальні методи мотивації, навчання персоналу. 